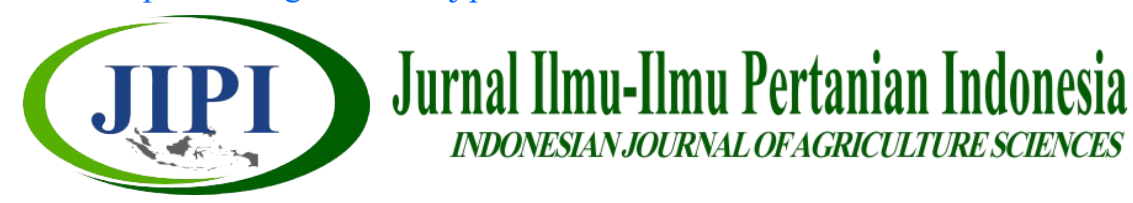

\title{
PERTUMBUHAN DAN HASIL SORGUM PADA PEMBERIAN BEBERAPA DOSIS PUPUK NPK MAJEMUK DI LAHAN PESISIR
}

\author{
Edi Susilo $^{1}$, Hesti Pujiwati ${ }^{2 *}$, Muhimmatul Husna ${ }^{2}$ \\ ${ }^{1}$ Program Studi Agroteknologi, Fakultas Pertanian Universitas Ratu Samban \\ ${ }^{2}$ Program Studi Agroekoteknologi, Fakultas Pertanian Universitas Bengkulu \\ *Corresponding Author: hesti_pujiwati@unib.ac.id
}

\begin{abstract}
[GROWTH AND YIELDS OF SORGHUM VARIETIES TREATED WITH VARIOUS DOSES OF NPK FERTILIZER IN COASTAL LAND]. Sorghum has a potential to be developed in marginal land in coastal area. Drought stress and low availability of utrients in the coastal area are the main problems in growing sorghum. Introducing the drought tolerance variety is one solution to overcome the drought stress in coastal land in order to improve sorghum yields. In addition, the treatment of NPK fertilizer is needed to fulfill the nutrients requirements for growth and yields. This research aims to determine the best sorghum variety and an appropriate dose of NPK fertilizer for the growing sorghum in coastal land. Field experiment was conducted at the coastal area in Bengkulu City from August until November 2021. The experiment was arranged in Randomized Completely Blok Design with two factors. That were sorghum varieties (Numbu, Super 2 and Kawali) and NPK fertilizer doses (150 kg/ha, 300 $\mathrm{kg} / \mathrm{ha}$ and $450 \mathrm{~kg} / \mathrm{ha}$ ). The results showed that the interaction between sorghum variety and NPK fertilizer dose were not significant on the growth and sorghum yields. Numbu varieties produced the highest panicle weight per plant of 69.42 gram. The research concluded that Numbu variety showed the best growth and yields compare two other varieties. The maximum growth and yield of sorghum in coastal land were observed at NPK $450 \mathrm{~kg} / \mathrm{ha} \mathrm{dose}$.
\end{abstract}

Keyword: drought stress, Kawali, nutrients, Numbu, Super 2

\begin{abstract}
ABSTRAK
Sorgum memiliki potensi untuk dikembangkan pada lahan marginal seperti lahan pesisir. Cekaman kekeringan dan rendahnya ketersediaan hara pada lahan pesisir menjadi kendala dalam budidaya tanaman sorgum. Penggunaan varietas sorgum yang toleran kekeringan dapat menjadi solusi pada lahan pesisir yang kering untuk meningkatkan hasil sorgum. Selain itu, pemberian pupuk NPK pada lahan pesisir dapat memenuhi kebutuhan hara bagi pertumbuhan dan peningkatan hasil tanaman sorgum. Penelitian ini bertujuan untuk menentukan varietas sorgum yang baik dan dosis pupuk NPK terbaik untuk pertumbuhan dan hasil sorgum di lahan pesisir. Penelitian dilakukan pada Agustus sampai November 2020 di lahan pesisir kota Bengkulu. Rancangan penelitian menggunakan RAKL dengan dua faktor yaitu varietas sorgum (Numbu, Super 2 dan Kawali) dan dosis pupuk NPK (150 kg/ha, $300 \mathrm{~kg} /$ ha dan $450 \mathrm{~kg} / \mathrm{ha}$ ). Hasil penelitian menunjukkan bahwa varietas dan dosis pupuk NPK berbeda nyata pada pertumbuhan dan hasil sorgum tapi tidak ada interaksi antara keduanya. Varietas Numbu menghasilkan bobot malai per tanaman paling tinggi yaitu 69,42 g. Disimpulkan bahwa sorgum varietas Numbu memiliki pertumbuhan dan hasil paling baik diantara dua varietas lainnya di lahan pesisir. Tanaman sorgum memberikan pertumbuhan dan hasil maksimal di lahan pesisir pada perlakuan dosis NPK $450 \mathrm{~kg} / \mathrm{ha}$.
\end{abstract}

Kata kunci: $\quad$ cekaman kekeringan, hara, Kawali, Numbu, Super 2 


\section{PENDAHULUAN}

Sorgum merupakan tanaman serealia yang berpotensi untuk dikembangkan. Sorgum sebagai salah satu pangan alternatif dengan kandungan nutrisi cukup tinggi dibandingkan dengan komoditi pangan utama lainnya, namun tingginya kadar tanin pada sorgum diperlukan pengolahan tambahan seperti perendaman. Nilai produksi dan produktivitas sorgum di Indonesia dari tahun 2005-2011 mengalami peningkatan. Produksi sorgum pada tahun 2011 mencapai 7.695 ton dan produktivitas 1,3 ton/ha (Subagio \& Suryawati, 2013). Namun, angka produksi dan produktivitas sorgum di Indonesia masih tergolong rendah karena kondisi lahan kering dan luas lahan pengembangan sorgum masih sedikit. Data terbaru produksi sorgum secara nasional dari Badan Pusat Statistik (BPS) maupun dari Balai Penelitian Tanaman Serealia tidak tersedia. Hal ini menjadi perhatian bahwa produksi sorgum masih sedikit dan belum terhitung dalam produksi pangan secara nasional.

Saat ini, upaya yang dilakukan untuk memenuhi kebutuhan pangan adalah meningkatkan hasil tanaman melalui penambahan luas lahan tanam dengan memanfaatkan lahan marginal. Salah satu lahan marginal yang dapat dijadikan sebagai lahan budidaya tanaman sorgum adalah lahan pesisir. Namun, masalah utama pada lahan pesisir berupa kekeringan dan ketersediaan hara rendah. Menurut Yuwono (2009) lahan pesisir merupakan lahan marginal dengan tekstur pasiran, struktur lepas-lepas, kandungan hara rendah, kemampuan menukar kation rendah, daya menyimpan air rendah, suhu tanah pada siang hari sangat tinggi, kecepatan angin dan laju evaporasi sangat tinggi. Permasalahan pada lahan kering adalah defisit air yang menyebabkan pertumbuhan, fotosintesis tanaman terganggu dan pada jaringan tanaman kekeringan terjadi penurunan konsentrasi senyawa $\mathrm{N}$ dan $\mathrm{N}$ total dan mempercepat penuaan pada daun (Chen et al., 2015; Supandie, 2013).

Potensi lahan pesisir sebagai lahan marginal untuk budidaya sorgum dapat dimanfaatkan dengan penggunaan varietas sorgum yang toleran kekeringan. Sorgum memiliki kemampuan toleran atau tahan terhadap lingkungan yang kering, masam dan salin sehingga dapat dimanfaatkan secara luas. Kemampuan sorgum toleran terhadap cekaman kekeringan cukup tinggi. Beberapa varietas sorgum yang dapat beradaptasi dengan baik pada lahan kering adalah varietas Numbu, Kawali, Unpad 1 dan Unpad 2 (Sutrisna et al., 2013). Menurut Asadi \& Eshghizadeh (2021) cekaman kekeringan dapat menurunkan berat kering tanaman dengan berkurangnya luas daun dan indeks stabilitas membran. Diharapkan dengan memilih varietas sorgum toleran kekeringan dapat mengurangi potensi rendahnya hasil dan pengaruh fisiologi tanaman terhadap pertumbuhan di lahan pesisir.

Permasalahan di lahan pesisir selain kekeringan adalah rendahnya ketersediaan unsur hara khususnya hara $\mathrm{N}, \mathrm{P}, \mathrm{K}$, dan juga rendahnya bahan organik (Bertham et al., 2020). Sebagaimana pada lahan pesisir yang digunakan untuk penelitian ini ketersediaan $\mathrm{N}$ sangat rendah dan $\mathrm{K}$ rendah. Hasil uji lahan berpasir oleh Darlita et al. (2017) menemukan bahwa lahan berpasir memiliki $\mathrm{pH}$ rendah, kandungan $\mathrm{N}$ total rendah $0,1 \%, \mathrm{~K}$ rendah $0,2 \mathrm{cmol} / \mathrm{kg}, \mathrm{P}$ total tinggi 50,91 ppm, C-organik sedang dan KTK rendah $9,44 \mathrm{cmol} / \mathrm{kg}$. Untuk memenuhi kebutuhan hara pada lahan pesisir perlu dilakukan pemupukan salah satunya dengan pemberian pupuk NPK majemuk. Dosis pupuk yang diberikan berkaitan erat dengan jenis tanah dan tingkat ketersediaan hara dalam tanah. Hal tersebut menjadi rekomendasi takaran pupuk yang sesuai spesifik lokasi. Menurut Syafruddin \& Akil (2013) pemupukan spesifik lokasi adalah pemupukan yang sesuai dengan potensi dan peluang hasil, kemampuan lahan menyediakan hara secara alami dan pemulihan hara. Oleh sebab itu perlu dilakukan pemupukan NPK majemuk spesifik lokasi khususnya daerah cekaman kekeringan pada lahan pesisir sehingga dosis pupuk NPK majemuk yang tepat dapat memenuhi kebutuhan hara N, P, dan K. Tujuan penelitian ini adalah menentukan varietas sorgum yang adaptif dan dosis pupuk NPK optimum untuk pertumbuhan dan hasil sorgum di lahan pesisir.

\section{METODE PENELITIAN}

Penelitian dilaksanakan pada bulan Agustus November 2020 di lahan pesisir tepatnya di Jl. Kuala Alam Kelurahan Nusa Indah Kecamatan Ratu Agung Kota Bengkulu Provinsi Bengkulu Bahan yang digunakan adalah benih sorgum varietas Numbu, Super 2 dan Kawali, pupuk NPK, air, fungisida dan insektisida. Benih sorgum varietas Numbu, Super 2, dan Kawali yang diperoleh dari Balai Penelitian Tanaman Serealia (Balitsereal) Jl. Dr. Ratulangi 274 Maros Sulawesi Selatan, pupuk majemuk NPK, kotoran ayam, insektisida berupa karbofuran dan Profenofos dan insektisida. Alat yang digunakan adalah cangkul, sabit, kored, rafia, gembor, mistar, jangka sorong, timbangan manual, timbangan digital, label percobaan, counter, kamera, dan alat tulis.

Rancangan percobaan menggunakan RAKL (Rancangan Acak Kelompok Lengkap) pola faktorial 2 faktor yaitu faktor pertama varietas sorgum dan faktor kedua dosis NPK. Faktor pertama yaitu tiga varietas sorgum berturut-turut Numbu, Super 2, dan Kawali. Faktor kedua tiga taraf dosis NPK yaitu $150 \mathrm{~kg} / \mathrm{ha}, 300 \mathrm{~kg} / \mathrm{ha}$, dan $450 \mathrm{~kg} / \mathrm{ha}$. Terdapat 9 kombinasi perlakuan dan diulang sebanyak 3 kali sehingga terdapat 27 satuan percobaan. Setiap satuan percobaan berupa petakan lahan percobaan berukuran $1,5 \mathrm{~m} \times 2,25 \mathrm{~m}$ yang merupakan unit percobaan pada penelitian ini. 
Pelaksanaan penelitian diawali dengan persiapan lahan berupa pengolahan tanah sebanyak satu kali dan dilanjutkan dengan pembuatan unit percobaan yang berupa petakan percobaan. Kegiatan selanjutnya yaitu berupa penaburan kotoran hewan ternak berupa kotoran ayam sebanyak 5 ton/ha diaplikasikan ditabur secara merata pada semua unit percobaan. Lahan percobaan didiamkan selama seminggu dan selanjutnya dilakukan pembuatan lubang tanam (tugal) dengan jarak tanam $75 \mathrm{~cm} \times 25 \mathrm{~cm}$ sehingga terdapat 18 populasi per petak percobaan. Pemberian karbofuran 10 butir per lubang tanam untuk pencegahan serangan hama tanah seperti semut maupun orong-orong. Penanaman benih sorgum sebanyak 4 butir per lubang tanam di petak percobaan sesuai perlakuan dan dilakukan penjarangan dengan menyisakan satu tanaman per lubang tanam pada umur 10 hst (hari setelah tanam). Pemupukan merupakan perlakuan pada percobaan ini dan dilakukan satu kali bersamaan dengan waktu tanam, diberikan sistem tugal tepatnya $5 \mathrm{~cm}$ di samping pertanaman sorgum.Pemeliharaan berikutnya berupa penyiraman dilakukan 1 kali sehari pada sore hari diawal penanaman sampai umur 3 minggu setelah tanam (mst). Pengendalian gulma dilakukan pada umur $3 \mathrm{mst}$ dan $6 \mathrm{mst}$ dengan cara manual berupa penyiangan dengan mencabut gulma secara langsung maupun menggunakan kored. Pengendalian hama ulat dilakukan sekali pada umur 6 mst dengan insektisida berbahan aktif Profenofos. Pemanenan dilakukan secara bertahap sesuai dengan kriteria panen yaitu biji mengering, biji matang fisiologis yang ditandai oleh lapisan pati yang keras dan biji berkembang sempurna atau bernas. Selain itu juga bisa diukur dari umur tanaman masingmasing varietas yaitu Numbu 100-105 hari, Super 2 115-120 hari, dan Kawali 100-110 hari (Balitsereal, 2021).

Analisis kimia dan tekstur tanah awal (sebelum tanam) di Laboratorium Departemen Ilmu Tanah dan Sumber Daya Lahan Fakultas Pertanian Institut Pertanian Bogor, Bogor. Variabel yang diamati adalah tinggi tanaman $(\mathrm{cm})$, jumlah daun (helai), panjang daun $(\mathrm{cm})$, lebar daun $(\mathrm{cm})$, luas daun $\left(\mathrm{cm}^{2}\right)$ mengguna-kan metode konstanta (Susilo, 2015), diameter batang (mm) diukur menggunakan jangka sorong manual, panjang malai $(\mathrm{cm})$, bobot 1000 butir $(\mathrm{g})$, bobot malai/tanaman $(\mathrm{g})$, bobot malai/petak (g), bobot biji/tanaman, bobot biji/ petak, dan hasil/ha.

Data yang diperoleh dari hasil pengamatan dianalisis menggunakan Anava pada taraf 5\%. Hasil analisis yang berbeda nyata kemudian diuji lanjut dengan DMRT taraf 5\% (Mattjik \& Sumertajaya, 2006).

\section{HASIL DAN PEMBAHASAN}

Hasil analisis sifat kimia tanah pesisir sebelum tanam adalah $\mathrm{N}$ tersedia sangat rendah, $\mathrm{P}$ tersedia sangat tinggi, $\mathrm{K}$ tersedia rendah, dan $\mathrm{C}$-Organik sangat tinggi
(Tabel 1). Berdasarkan hasil uji tanah awal, lahan bertekstur berpasir dan tidak tergolong salin. Menurut Tabri \& Zubachtirodin (2013), kondisi N sangat rendah, P tinggi, $\mathrm{K}$ rendah dan tekstur tanah berpasir tergolong sesuai untuk tanaman sorgum berdasarkan pada tingkat kesesuaian lahan pesisir atau sesuai marginal. Kondisi lahan pesisir dengan $\mathrm{C}$-organik dan $\mathrm{P}$ tersedia sangat tinggi menjadi faktor pendukung untuk pemupukan NPK majemuk karena upaya perbaikan sifat kimia tanah hanya perlu pemupukan $\mathrm{N}$ dan $\mathrm{K}$ yang tinggi.

Tanah berpasir merupakan tanah marginal dengan tingkat kekeringan yang cukup tinggi. Kekeringan menjadi kendala bagi pertumbuhan dan produksi tanaman sorgum meskipun sorgum memiliki sifat toleran terhadap kekeringan. Tingkat simulasi kekeringan yang dilakukan oleh Chaniago et al. (2017) pada beberapa varietas sorgum tahap pembibitan menunjukkan bahwa pada kekeringan 20\% PEG varietas Samurai 2 mampu tumbuh dengan baik. Sedangkan pada tahap kekeringan $25 \%$ mulai terjadi kegagalan produksi gabah dan penurunan produksi biomasa. Selain itu, hasil penelitian oleh Sarshad et al. (2021) cekaman kekeringan pada tahap cekaman kekeringan sedang menyebabkan terjadinya penurunan hasil yang tidak besar. Namun secara umum, cekaman kekeringan tidak berpengaruh terhadap sifat morfologi dan hasil sorgum. Hal ini berarti tanaman sorgum memiliki potensi toleran pada lahan kering tergantung pada kondisi tingkat kekeringan pada lahan tersebut.

Tabel 1. Analisis sifat kimia dan tekstur tanah pesisir sebelum tanam

\begin{tabular}{lll}
\hline \multicolumn{1}{c}{ Sifat Kimia } & \multicolumn{1}{c}{ Nilai } & Keterangan \\
\hline $\mathrm{pH}\left(\mathrm{H}_{2} \mathrm{O}\right)$ & 5,93 & Agak masam \\
C-Organik & $6,13 \%$ & Sangat tinggi \\
N-total (Kjeldahl) & $0,04 \%$ & Sangat rendah \\
$\mathrm{P}$ (Bray I) & $19,84 \mathrm{ppm}$ & Sangat tinggi \\
$\mathrm{K}$ & $0,13 \mathrm{cmol}^{(+)} / \mathrm{kg}$ & Rendah \\
$\mathrm{Na}$ & $0,08 \mathrm{cmol}^{(+) / \mathrm{kg}}$ & Sangat rendah \\
$\mathrm{KTK}$ & $16,76 \mathrm{cmol}^{(+) / \mathrm{kg}}$ & Rendah \\
\hline Tekstur (Metode Pipet) & & \\
Pasir & $91,32 \%$ & Berpasir \\
Debu & $1,95 \%$ & \\
Liat & $6,73 \%$ & \\
\hline Sumber : Hasil uji tanah di laboratorium Departemen Ilmu Tanah dan \\
Sumber Daya Lahan, Fakultas Pertanian, Institut Pertanian Bogor,
\end{tabular}

Hasil analisis statistik menunjukkan bahwa perlakuan berbagai varietas sorgum berbeda nyata pada variabel vegetatif dan hasil sorgum kecuali bobot 1000 butir (Tabel 2). Demikian juga perlakuan dosis pupuk NPK berbeda nyata pada pertumbuhan vegetatif sorgum kecuali tinggi tanaman dan jumlah daun. Perlakuan dosis pupuk NPK juga berbeda nyata pada variabel bobot malai pertanaman dan bobot biji per tanaman. Namun interaksi antara varietas sorgum dengan dosis pupuk NPK berbeda tidak nyata terhadap semua variabel yang diamati. Sebaliknya pada hasil penelitian Sitepu et al. (2015) pemberian dosis fosfor 
memberikan perbedaan nyata pada tinggi dan hasil varietas sorgum Kawali, Pahat, Mandau dan Numbu.

Pada umumnya, setiap varietas memiliki kemampuan tumbuh pada kondisi lahan yang berbeda. Selain itu, keragaan masing-masing varietas juga akan memberikan perbedaan pertumbuhan pada beberapa dosis pemupukan. Hasil penelitian ini menunjukkan bahwa tidak ada interaksi antara varietas dan dosis pupuk NPK yang diberikan. Hal ini terjadi karena varietas Numbu, Super 2 dan Kawali dapat beradaptasi dengan baik pada kondisi lahan $\mathrm{N}$ sangat rendah dan $\mathrm{K}$ rendah meskipun diberikan pupuk NPK majemuk. Menurut Lemaire et al. (1996) serapan hara $\mathrm{N}$ oleh sorgum cukup tinggi bahkan serapan hara berlangsung hingga sebelum hara $\mathrm{N}$ terbatas. Laju serapan $\mathrm{N}$ lebih spesifik pada perkembangan fisiologi akar sorgum hibrida daripada varietas lokal (Nakamura et al., 2002). Artinya varietas Numbu, Super 2 dan Kawali yang merupakan varietas unggul, menyerap hara $\mathrm{N}$ banyak untuk memenuhi kebutuhan $\mathrm{N}$ pada jaringan tanaman.

Varietas Numbu, Super 2, dan Kawali menunjukkan pertumbuhan dan hasil maksimal pada lahan cekaman kekeringan dan hara $\mathrm{N}, \mathrm{P}$, dan $\mathrm{K}$ rendah. Varietas Numbu, Super 2 dan Kawali adaptif terhadap lahan pesisir sehingga tidak terjadi interaksi pada dosis pupuk NPK majemuk yang diberikan pada dosis 150 $\mathrm{kg} / \mathrm{ha}-450 \mathrm{~kg} / \mathrm{ha}$. Berbeda dengan hasil yang diperoleh oleh Sawargaonkar et al. (2013) pertumbuhan kultivar sorgum berpengaruh pada pemberian $\mathrm{N}$ hingga 150 $\mathrm{kg} \mathrm{N} / \mathrm{ha}$ meskipun nilai Efisiensi Penggunaan $\mathrm{N}(N U E)$ menunjukkan hanya pada dosis $90 \mathrm{~kg} \mathrm{~N} / \mathrm{ha}$. setiap kultivar sorgum memiliki respon yang berbeda pada dosis $\mathrm{N}$ yang berbeda (Syahfriani et al. , 2012)
Pengaruh varietas terhadap pertumbuhan dan hasil sorgum

Varietas sorgum berpengaruh nyata terhadap pertumbuhan dan hasil sorgum. Variabel pertumbuhan sorgum yaitu tinggi, panjang daun, lebar daun, dan luas daun pada varietas Numbu dan Super 2 berbeda tidak nyata. Varietas Kawali memiliki nilai yang paling rendah pada tinggi, panjang, lebar dan luas daun. Namun pada jumlah daun, diameter batang dan panjang malai varietas Kawali memiliki jumlah daun paling banyak yaitu 16 helai, diameter batang paling besar yaitu $19,76 \mathrm{~cm}$ dan panjang malai terpanjang $25,96 \mathrm{~cm}$ (Tabel 3).

Pertumbuhan varietas sorgum Numbu, Super 2 dan Kawali pada lahan pesisir tidak mengalami gangguan cekaman abiotik kekeringan. Varietas-varietas tersebut memiliki sifat toleran terhadap kondisi lahan pesisir di Bengkulu yang berpasir dan ketersediaan hara NPK rendah. Berdasarkan hasil penelitian Yunita et al. (2012), pada 12 kultivar sorgum yang diuji pada cekaman kekeringan tidak terdapat pengaruh nyata cekaman kekeringan 12 kultivar sorgum pada jumlah daun namun berbeda nyata pada tinggi tanaman dan diameter batang. Pertumbuhan varietas Numbu dan Kawali yang tidak jauh berbeda dari deskripsi varietas didukung dengan pemberian pupuk NPK majemuk. Sebaliknya varietas Super 2 memiliki tinggi dan panjang malai yang lebih rendah dari deskripsi varietasnya.

Variabel tinggi dan jumlah daun yang diperoleh dari penelitian ini memiliki nilai yang lebih tinggi dan tidak jauh berbeda dengan nilai dari deskripsi varietas sorgum Numbu dan Kawali.

Tabel 2. Rekapitulasi pertumbuhan dan hasil beberapa varietas sorgum akibat perlakuan pupuk NPK

\begin{tabular}{clcccc}
\hline No & Variabel pengamatan & $\begin{array}{c}\text { Varietas } \\
\text { Sorgum }(\mathrm{G})\end{array}$ & $\begin{array}{c}\text { Dosis NPK } \\
(\mathrm{P})\end{array}$ & $\begin{array}{c}\text { Interaksi } \\
(\mathrm{G} \mathrm{x} \mathrm{P})\end{array}$ & $\begin{array}{c}\text { Koefisien } \\
\text { keragaman }(\%)\end{array}$ \\
\hline 1 & Tinggi tanaman & $13,65 * *$ & $1,51 \mathrm{tn}$ & $1,00 \mathrm{tn}$ & 14,30 \\
2 & Jumlah daun & $26,01 * *$ & $4,49 *$ & $0,19 \mathrm{tn}$ & 4,63 \\
3 & Panjang daun & $17,65 * *$ & $9,95 * *$ & $0,46 \mathrm{tn}$ & 3,27 \\
4 & Lebar daun & $13,52 * *$ & $21,28 * *$ & $2,57 \mathrm{tn}$ & 4,06 \\
5 & Luas daun & $26,69 * *$ & $26,37 * *$ & $1,97 \mathrm{tn}$ & 5,56 \\
6 & Diameter batang & $3,77 *$ & $12,45 * *$ & $0,64 \mathrm{tn}$ & 6,12 \\
7 & Panjang malai & $12,13 * *$ & $0,05 \mathrm{tn}$ & $1,11 \mathrm{tn}$ & 12,58 \\
8 & Bobot 1000 butir & $1,35 \mathrm{tn}$ & $0,62 \mathrm{tn}$ & $2,00 \mathrm{tn}$ & 3,16 \\
9 & Bobot malai/tanaman & $117,94 * *$ & $55,92 * *$ & $2,60 \mathrm{tn}$ & 12,46 \\
10 & Bobot malai/petak & $28,44 * *$ & $0,89 \mathrm{tn}$ & $2,20 \mathrm{tn}$ & 29,09 \\
11 & Bobot biji/tanaman & $117,91 * *$ & $55,93 * *$ & $2,59 \mathrm{tn}$ & 12,47 \\
12 & Bobot biji/petak & $28,42 * *$ & $0,88 \mathrm{tn}$ & $2,20 \mathrm{tn}$ & 29,08 \\
13 & Bobot biji/ha & $28,54 * *$ & $0,89 \mathrm{tn}$ & $2,20 \mathrm{tn}$ & 28,99 \\
\hline
\end{tabular}

\footnotetext{
Keterangan: * = berbeda nyata;

*** = berbeda sangat nyata

tn $=$ tidak berbeda nyata
} 
Seperti tinggi dan jumlah daun sorgum varietas Numbu tinggi tanaman $\pm 187 \mathrm{~cm}$ dan varietas Kawali 135 $\mathrm{cm}$ (Balitsereal, 2019) dan tinggi sorgum yang diperoleh pada lahan pesisir adalah $221,7 \mathrm{~cm}$ dan $155,96 \mathrm{~cm}$. Pada varietas Super 2, tinggi tanaman dan panjang malai berdasarkan deskripsi varietas $229,7 \mathrm{~cm}$ dan $26,3 \mathrm{~cm}$ (BalitSereal, 2019). Hasil yang diperoleh pada penanaman di lahan pesisir adalah 205,37 $\mathrm{cm}$ dan $24,58 \mathrm{~cm}$ (Tabel 3). Meskipun tinggi dan panjang malai varietas Super 2 lebih rendah dari deskripsi varietas, jumlah daun yang dihasilkan pada penelitian ini lebih banyak yaitu 15 helai.

Varietas Numbu memiliki nilai bobot malai per tanaman paling tinggi yaitu 69,42 g. Bobot biji/petak varietas Numbu dua kali lipat dibandingkan dengan varietas Super 2 dan Kawali (Tabel 4). Artinya varietas Numbu merupakan varietas yang toleran dan berpotensi untuk dikembangkan di lahan pesisir. Sama halnya pada hasil penelitian Siregar \& Mardiyah (2018) Varietas Numbu memberikan produksi terbaik dan dapat beradaptasi dengan baik pada lahan sawah tadah hujan. Walaupun hasil varietas Numbu pada penelitian ini tergolong rendah $(3,23$ ton/ha) jika dibandingkan dengan potensi hasil Numbu mencapai 4,0-5,0 ton/ha, varietas Numbu dapat dikembangkan di lahan pesisir. Hasil varietas Kawali dan Super 2 hanya mencapai 1,16 ton/ha dan 1,78 ton/ha.

Tanaman sorgum varietas Numbu dapat tumbuh baik dan menghasilkan hasil yang optimum pada lahan kering karena memiliki sifat toleran kekeringan. Menurut Susilo et al. (2020) sorgum mempunyai kemampuan adaptasi luas terhadap cekaman biotik maupun abiotik seperti mampu beradaptasi di lingkungan kering.

Tabel 3. Rataan variabel pertumbuhan sorgum pada perlakuan varietas sorgum dan dosis pupuk NPK

\begin{tabular}{lccccccc}
\hline Perlakuan & $\begin{array}{c}\text { Tinggi } \\
(\mathrm{cm})\end{array}$ & $\begin{array}{c}\text { Jumlah } \\
\text { daun } \\
\text { (helai) }\end{array}$ & $\begin{array}{c}\text { Panjang } \\
\text { daun } \\
(\mathrm{cm})\end{array}$ & $\begin{array}{c}\text { Lebar } \\
\text { daun } \\
(\mathrm{cm})\end{array}$ & $\begin{array}{c}\text { Luas } \\
\text { daun } \\
\left(\mathrm{cm}^{2}\right)\end{array}$ & $\begin{array}{c}\text { Diameter } \\
\text { batang } \\
(\mathrm{mm})\end{array}$ & $\begin{array}{c}\text { Panjang } \\
\text { malai } \\
(\mathrm{cm})\end{array}$ \\
\hline Varietas : & & & & & & & \\
$\quad$ Numbu & $221,70 \mathrm{a}$ & $13,70 \mathrm{c}$ & $89,79 \mathrm{a}$ & $8,85 \mathrm{a}$ & $582,44 \mathrm{a}$ & $18,43 \mathrm{~b}$ & $21,17 \mathrm{~b}$ \\
$\quad$ Super 2 & $205,37 \mathrm{a}$ & $14,55 \mathrm{~b}$ & $91,19 \mathrm{a}$ & $9,01 \mathrm{a}$ & $601,69 \mathrm{a}$ & $18,50 \mathrm{~b}$ & $24,58 \mathrm{a}$ \\
Kawali & $155,96 \mathrm{~b}$ & $16,00 \mathrm{a}$ & $83,59 \mathrm{~b}$ & $8,19 \mathrm{~b}$ & $500,38 \mathrm{~b}$ & $19,76 \mathrm{a}$ & $25,96 \mathrm{a}$ \\
\hline Pupuk NPK & & & & & & & \\
(kg/ha): & & & & & & & \\
150 & 181,41 & $14,26 \mathrm{~b}$ & $84,79 \mathrm{~b}$ & $8,15 \mathrm{c}$ & $505,87 \mathrm{c}$ & $17,45 \mathrm{~b}$ & 23,72 \\
300 & 202,82 & $14,78 \mathrm{ab}$ & $89,19 \mathrm{a}$ & $8,67 \mathrm{~b}$ & $566,11 \mathrm{~b}$ & $19,09 \mathrm{a}$ & 23,98 \\
450 & 198,82 & $15,22 \mathrm{a}$ & $90,59 \mathrm{a}$ & $9,23 \mathrm{a}$ & $612,52 \mathrm{a}$ & $20,14 \mathrm{a}$ & 24,00 \\
\hline
\end{tabular}

Keterangan : angka-angka yang diikuti huruf yang sama pada kolom yang sama berbeda tidalk nyata pada DMRT taraf $5 \%$

Tabel 4. Rataan variabel hasil sorgum pada perlakuan varietas sorgum dan dosis pupuk NPK

\begin{tabular}{|c|c|c|c|c|c|c|}
\hline Perlakuan & $\begin{array}{c}\text { Bobot } 1000 \\
\text { butir }(\mathrm{g})\end{array}$ & $\begin{array}{c}\text { Bobot } \\
\text { malai/ } \\
\text { tanaman } \\
\text { (g) }\end{array}$ & $\begin{array}{c}\text { Bobot } \\
\text { malai/ } \\
\text { petak (g) }\end{array}$ & $\begin{array}{c}\text { Bobot } \\
\text { biji/ } \\
\text { tanaman } \\
\text { (g) }\end{array}$ & $\begin{array}{c}\text { Bobot biji/ } \\
\text { petak }(\mathrm{g})\end{array}$ & $\begin{array}{c}\text { Bobot biji/ } \\
\text { ha (ton) }\end{array}$ \\
\hline \multicolumn{7}{|l|}{ Varietas: } \\
\hline Numbu & 71,22 & $69,42 \mathrm{a}$ & $716,53 \mathrm{a}$ & $62,48 \mathrm{a}$ & $644,88 \mathrm{a}$ & $3,23 \mathrm{a}$ \\
\hline Super 2 & 71,00 & $33,05 \mathrm{~b}$ & $396,50 \mathrm{~b}$ & $29,75 \mathrm{~b}$ & $355,85 \mathrm{~b}$ & $1,78 \mathrm{~b}$ \\
\hline Kawali & 72,17 & $34,50 \mathrm{~b}$ & $256,39 \mathrm{c}$ & $31,05 \mathrm{~b}$ & $230,75 \mathrm{c}$ & $1,16 \mathrm{c}$ \\
\hline \multicolumn{7}{|l|}{$\begin{array}{l}\text { Pupuk NPK } \\
\text { (kg/ha) }\end{array}$} \\
\hline 150 & 71,17 & $31,37 \mathrm{c}$ & 409,93 & $28,24 \mathrm{c}$ & 368,94 & 1,85 \\
\hline 300 & 71,28 & $45,87 \mathrm{~b}$ & 489,76 & $41,28 \mathrm{~b}$ & 440,78 & 2,20 \\
\hline 450 & 71,94 & $59,73 \mathrm{a}$ & 469,73 & $53,76 \mathrm{a}$ & 422,76 & 2,12 \\
\hline
\end{tabular}

Keterangan : angka-angka yang diikuti huruf yang sama pada kolom yang sama berbeda tidalk nyata pada DMRT taraf $5 \%$ 
Selanjutnya menurut Johnson et al. (2014) terdapat proses biologi gen ontologi respon stres, biosintesis poliol, lokalisasi lipid, regulasi fotosintesis dan metabolisme karbohidrat pada tanaman sorgum ketika beradaptasi pada cekaman kekeringan. Selain itu, saat menanggapi stres kekeringan terdapat perubahan gen 3,5\% yang berubah lebih dari dua kali lipat pada tanaman sorgum yang sebagian besar gen memiliki toleransi kekeringan seperti responsif $\mathrm{ABA}$ yang diinduksi oleh terjadinya dehidrasi.

\section{Pengaruh pupuk NPK terhadap pertumbuhan dan hasil sorgum}

Dosis pupuk NPK berpengaruh nyata pada variabel vegetatif tanaman sorgum kecuali tinggi tanaman dan panjang malai, juga berbeda nyata pada bobot malai/tanaman dan bobot biji/tanaman. Perlakuan dosis pupuk NPK $450 \mathrm{~kg} / \mathrm{ha}$ menghasilkan nilai paling tinggi untuk variabel jumlah daun, panjang daun, lebar daun, luas daun, diamater batang, dan bobot malai/tanaman meskipun jumlah daun, panjang daun dan diameter batang berbeda tidak nyata dengan perlakuan dosis NPK $300 \mathrm{~kg} / \mathrm{ha}$. Pada perlakuan dosis NPK $150 \mathrm{~kg} /$ ha diperoleh nilai pertumbuhan paling kecil di antara dua dosis NPK lainnya. Pada variabel hasil sorgum, Bobot malai per tanaman dan bobot biji pertanaman paling rendah pada dosis NPK $150 \mathrm{~kg} /$ ha yaitu 31,37 $\mathrm{g}$ dan 409,93 g. Meskipun bobot biji/petak dan bobot biji/ha berbeda tidak nyata pada dosis NPK $300 \mathrm{~kg} / \mathrm{ha}$ dan $450 \mathrm{~kg} / \mathrm{ha}$. Nilai pertumbuhan dan hasil sorgum pada perlakuan dosis pupuk NPK terdapat pada Tabel 3 dan Tabel 4.

Pengaruh dosis NPK terhadap pertumbuhan dan hasil tanaman sorgum sangat besar. Pada pemberian dosis NPK $150 \mathrm{~kg}$ /ha belum dapat memenuhi kebutuhan hara sorgum untuk memperoleh hasil yang maksimal. Pertumbuhan maksimal sorgum dapat diperoleh dengan terpenuhinya kebutuhan hara khususnya hara $\mathrm{N}, \mathrm{P}$, dan K. Meskipun tinggi dan luas daun tanaman sorgum berpengaruh tidak nyata pada perlakuan dosis NPK. Berdasarkan hasil penelitian Andayani (2020) menunjukkan bahwa tinggi tanaman sorgum berbeda tidak nyata antara $100 \%$ dosis NPK rekomendasi dengan $70 \%$ dan 50\% untuk varietas Kawali. Sedangkan varietas Numbu tinggi tanaman berbeda tidak nyata pada dosis NPK 100\% rekomendasi dan NPK 75\%. Potensi hasil varietas Numbu tetap optimal pada dosis NPK 25\% rekomendasi dengan rata-rata hasil 6,55 ton/ha.

Rendahnya nilai bobot malai/tanaman yang diperoleh pada dosis NPK $150 \mathrm{~kg} / \mathrm{ha}$ karena tidak terpenuhinya hara pada awal pertumbuhan yang mempengaruhi pada hasil sorgum. Kebutuhan hara $\mathrm{N}$ untuk pertumbuhan sorgum pada fase vegetatif sebanyak $3,0-4,0 \%$, P $0,2-0,4 \%$ dan $\mathrm{K} 2 \%$, sedangkan pada fase pembungaan $\mathrm{N}$ dibutuhkan $2,5-4,0 \%, \mathrm{P} \quad 0,2-0,35 \%$ dan $\mathrm{K}$ 1,4\% (Espinoza, 2013). Berdasarkan hasil pengujian oleh Tabri \& Zubachtirodin (2013) di tanah aluvial Bojonegoro menunjukkan bahwa takaran pupuk $\mathrm{N}$ optimum untuk sorgum adalah 90 $\mathrm{kg} \mathrm{N} / \mathrm{ha}$ dan pada lahan kering $100 \mathrm{~kg} \mathrm{~N} / \mathrm{ha}$. Jadi dibutuhkan dosis NPK yang lebih tinggi pada lahan kering. Hal ini disebabkan karena pada tanah dengan cekaman kekeringan terjadi transpirasi $\mathrm{N}$ dengan penurunan 20-45\% N (Sawargaonkar et al., 2013). Sehingga hasil yang diperoleh pada penelitan ini, bobot malai/ tanaman pada dosis NPK $450 \mathrm{~kg} / \mathrm{ha}$ dan $300 \mathrm{~kg} / \mathrm{ha}$ berbeda tidak nyata karena $\mathrm{N}$ yang diberikan pada dosis NPK $450 \mathrm{~kg} / \mathrm{ha}$ cukup banyak yang hilang. Resiko kehilangan hara ini dapat dilakukan upaya pemupukan di lahan pesisir dengan menambahkan pupuk hayati dan biokompos maupun bahan organik lainnya selain pupuk anorganik NPK majemuk. Berdasarkan hasil penelitian Bertham et al. (2020) penambahan pupuk hayati dan biokompos pada lahan pesisir mampu meningkatkan serapan hara bagi tanaman padi gogo dan memperbaiki sifat biologi tanah pesisir.

Berdasarkan hasil penelitian ini, dosis NPK $450 \mathrm{~kg} / \mathrm{ha}$ memberikan pertumbuhan dan hasil paling tinggi meskipun berbeda tidak nyata dengan dosis $300 \mathrm{~kg} / \mathrm{ha}$. Pemberian dosis NPK $450 \mathrm{~kg} / \mathrm{ha}$ pada lahan pesisir dapat memenuhi kebutuhan hara untuk pertumbuhan dan hasil tanaman sorgum yang maksimal. Hara $\mathrm{N}$ merupakan faktor pembatas utama, kemudian $\mathrm{K}$ dan paling ringan adalah $\mathrm{P}$, tanpa adanya $\mathrm{N}$ maka hasil panen sangat rendah (Suminar et al., 2017). Sorgum memerlukan banyak N pada 60 hari setelah tanam yaitu sebanyak $60 \%$ dari total $\mathrm{N}$ yang dibutuhkan (Espinoza, 2013). Jika dibandingkan dengan kondisi tanah pesisir yang diuji dengan kadar P 19,84 ppm, untuk memenuhi target produksi biji sorgum 5 ton/ ha dibutuhkan dosis $20 \mathrm{~kg} \mathrm{P}_{2} \mathrm{O}_{5} / \mathrm{ha}$ (Syafruddin \& Akil, 2003). Pada kondisi kadar K rendah untuk memenuhi target produksi biji sorgum 5 ton/ha dibutuhkan dosis $74 \mathrm{~kg} \mathrm{~K}_{2} \mathrm{O} / \mathrm{ha}$ atau $\pm 462,5 \mathrm{~kg}$ NPK.

\section{KESIMPULAN}

Varietas Numbu, Super 2, dan Kawali bersifat adaptif pada lahan pesisir dengan kondisi kekeringan dan rendah hara. Varietas Numbu menunjukkan hasil yang paling baik di antara dua varietas lainnya (3,23 ton/ha). Tanaman sorgum memberikan pertumbuhan dan hasil maksimal di lahan pesisir pada perlakuan dosis NPK $450 \mathrm{~kg} / \mathrm{ha}$.

\section{DAFTAR PUSTAKA}

Andayani, R. D. (2020). Respon sorgum (Sorghum bicolor) terhadap pengurangan dosis pupuk anjuran. Buana Sains, 20(2),209-216.

Asadi, M. \& Eshghizadeh, H.R. ( 2021). Response of sorghum genotypes to water dificit stress 
under different $\mathrm{CO}_{2}$ and nitrogen levels. Plant Physiology and Biochemistry, 158,255-264. DOI: https://doi.org/10.1016/j.plaphy. 2020. 11.010.

Balitsereal (Balai Penelitian Tanaman Sereal). (2021). Database Sorgum (Daftar Varietas Sorgum Balitsereal). http://balitsereal.litbang.pertanian. go. id/varietas-sorgum/. 24 Maret 2021.

Balitsereal (Balai Penelitian Tanaman Serealia). (2019). Varietas Unggul Sorgum. Seri Tanaman Pangan. Pusat Perpustakaan dan Penyebaran Teknologi Pertanian Kementerian Pertanian Republik Indonesia, Sulawesi Selatan.

Bertham, Y.H., Nusantara, A.D., Murcitro, B.G. \& Arifin, Z. (2020). Perubahan karakteristik tanah dan penampilan beberapa varietas padi gogo pada kawasan pesisir dengan penambahan pupuk hayati dan biokompos. J.Ilmu-Ilmu Pertanian Indonesia, 22(2), 79-84. DOI: https://doi.org10.31186/jipi.22.2.79-84.

Chaniago, I., Syarif, A. \& Riviona, P. (2017). Sorghum seedling drought response: in search of tolerant genotypes. International Journal on Advanced Science Engineering Information Technology, 7(3), 892-897.

Chen, D., Wang, S., Xiong, B., Cao, B. \& Deng, X. (2015). Carbon/nitrogen imbalance associated with drought induced leaf senescence in Sorghum bicolor. Plos One, DOI:https:// doi.org/10.1371/journal.pone.0137026.

Espinoza, L. (2013). Fertilization and liming. Grain sorghum production handbook., United States Department of Agriculture, and County Gover ments Cooperating, University of Arkansas, 21 -24. https://www.uaex.edu/publications/pdf/ mp297/4 fertilization lime.pdf.

Johnson, S.M., Lim, F.L., Finkler, A., Fromm, H. \& Slabas, A.R. (2014). Transcriptomic analysis of Sorghum bicolor responding to combined heat and drought stress. BMC Genomics, 15,456.

Lemaire, G., Charrier, X. \& Hebert, Y. (1996). Nitrogen uptake capacities of maize and sorghum crops in different nitrogen and water supply conditions. Agronomie, 16, 231-246.

Mattjik, A.A. \& Sumertajaya, I.M. (2006). Perancangan Percobaan dengan Aplikasi SAS dan MINITAB. IPB Press., Bogor.

Nakamura, T., Joseph, J., Adu-Gyamfi, Yamamoto, A., Ishikawa, S., Nakano, H. \& Ito, O. (2002). Variental differences in root growth as related to nitrogen uptake by sorghum plants in lownitrogen environment.Plant and Soil,245,17-24.

Sarshad, A., Talei, D., Torabi, M., Rafiel, F. \& Nejatkah, P. (2021). Morphological and biochemical responses of Sorghum bicolor L. Moench under drought stress. SN Applied Sciences, 3, 81. DOI: https://doi.org/10.1007/ s42452-020-03977-4.
Sawargaonkar, G.L., Patil, M.D., Wani, S.P., Pavani, E., Reddy, B.V.S.R. \& Marimuthu, S. (2013). Nitrogen response and nitrogen efficiency of sweet sorghum cultivars. Field Crop Research, 149, 245-251. DOI: http://dx.doi.org/10.1016/ j.fcr.2013.05.009

Siregar, D.S. \& Mardiyah, A. (2018). Uji adaptasi beberapa varietas sorgum (Sorghum bicolor L.) pada pada lahan sawah tadah hujan di desa Marang Sutui Kota Langsa. Agrosamudra, 5(2), 80-86.

Sitepu, L., Zuhry, E. \& Nurbaiti. (2015). Aplikasi beberapa dosis pupuk fosfor untuk pertumbuhan dan produksi beberapa varietas sorgum (Sorghum bicolor (L). Moench). Jom Faperta, 2(2).

Sopandie, D. (2013). Fisiologi Adaptasi Tanaman terhadap Cekaman Abiotik pada Agroekosistem Tropika. IPB Press., Bogor.

Subagio, H. \& Suryawati. (2013). Wilayah Penghasil dan Ragam Penggunaan Sorgum di Indonesia. Dalam Sumarno, D. D. Said, M. Syam dan Hermanto (Eds). Sorgum Inovasi Teknologi dan Pengembangan. Badan Penelitian dan Pengembangan Kementerian Pertanian. IAARD Press, Jakarta.

Suminar, R., Suwarto \& Purnamawati, H. (2017). Penentuan dosis optimum pemupukan N, P dan K pada sorgum (Sorghum bicolor L.) Moench. JIPI, 22(1), 6-12. DOI: https://doi.org/10. 18343/jipi.22.1.6.

Susilo, D. E. H. (2015). Identifikasi nilai konstanta bentuk daun untuk pengukuran luas daun metode panjang kali lebar pada tanaman hortikultura di tanah gambut. Anterior Jurnal, 14(2),139 - 146.

Susilo, E. Fahrurrozi. \& Sumardi. 2020. Pengembangan produksi sorgum di lahan rawa : kajian pemanfaatan alelopati sebagai bioherbisida. Jurnal Agroqua: Media Informasi Agronomi dan Budidaya Perairan, 18(1),75-107. DOI: https://doi.org/10.32663/ja.v18i1.1215.

Sutrisna, N., Sunandar, N. \& Zubair, A. (2013). Uji adaptasi beberapa varietas sorgum (Sorghum bicolor L.) pada lahan kering di Kabupaten Ciamis, Jawa Barat. Jurnal Lahan Supoptimal, 2(2), 137-143.

Syafruddin \& Akil, M. (2013). Pengelolaan hara pada tanaman sorgum. Dalam Sumarno, D.S. Damardjati, M. Syam dan Hermanto (Eds). Sorgum Inovasi Teknologi dan Pengembangan. IAARD Press.,BadanPenelitiandan Pengembangan Pertanian Kementerian Pertanian, Jakarta.

Syahfriani, Taryono \& Suprianta. (2012). Efisiensi penggunaan nitrogen sepuluh kultivar sorgum manis (Sorghum bicolor L.(Moench)). Vegetalika, 1 (1).DOI:https://doi.org/10.22146/veg. 1395.

Tabri, F. \& Zubachtirodin. (2013). Budidaya tanaman sorgum. Dalam Sumarno, D.S. Damardjati, M. Syam dan Hermanto (Eds). Sorgum Inovasi 


\section{SUSILO et al.}

Teknologi dan Pengembangan. IAARD Press. Yuwono, N.W. (2009). Membangun kesuburan tanah Badan Penelitian dan Pengembangan Pertanian di lahan marginal. Jurnal Ilmu Tanah dan Kementerian Pertanian, Jakarta.

Yunita, T. R., Taryono \& Nasrullah. (2012). Keragaan Lingkungan, 9(2),137-141. sorgum manis (Sorghum bicolor L. Moench) pada kondisi tercekam kekeringan. Vegetalika, 1 (2). DOI: https://doi.org/10.22146/veg. 1363. 